\title{
Antioxidant activity and immune-enhancing effect of aqueous leaf extract of Elaeagnus multiflora Thunb.
}

\author{
Mi Ri Kim, Young Uk Kim, So Jeong Im, A Ra Jo, Gyu Ok Lee, Ja Won Shin, \\ Hu Won Kang, Hak Joon Choi, Seul Gi Lee, Cho Een Kim, Hak Sung Lee, \\ Jaeyong Kim*, Chul Yung Choi* \\ Jeonnam Institute of Natural Resources Research, Jangheung 59338, Korea
}

\begin{abstract}
In this study, we aimed to investigate the antioxidant and immunopotentiating effects of leaves of cheny elaeagnus (Elaeagnus multiflora, Em). The leaf, stem, and root of Em have been used in Kampo medicine. There are data on the therapeutic effects of $\mathrm{Em}$ fruit, but no information on its leaves. We thus investigated the antioxidant and immunopotentiating effects of Em leaf extract. $\mathrm{Balb} / \mathrm{c}$ mouse spleen cells were treated with concanavalin $\mathrm{A}$ and hot aqueous Em leaf extract $(50,100$, and $200 \mu \mathrm{g} / \mathrm{mL})$, and the effects on spleen cell proliferation and the secretion of interleukin (IL)-2, IL-4, and IL-10 were evaluated. A concentration-dependent increase in the secretion of IL-2 and IL-4 cytokines was observed, with concentrations of $1.86 \mathrm{pg} / \mathrm{mL}$ of IL-2 and $37.63 \mathrm{pg} / \mathrm{mL} \mathrm{of} \mathrm{IL-4} \mathrm{when} \mathrm{cells}$ were treated with $200 \mu \mathrm{g} / \mathrm{mL}$ of the extract. Natural killer (NK) cell activity was determined based on a co-culture of spleen cells and Yac-1 cells. NK activity gradually increased in a concentration-dependent manne. Further, 2,2-diphenyl-1-picrylhydrazyl radical scavenging activity was $58.5 \%$ and 2,2'-azino-bis(3-ethylbenzothiazoline-6sulfonic acid) radical scavenging activity was $78.2 \%$ with an extract concentration of $200 \mu \mathrm{g} / \mathrm{mL}$. The high antioxidant activity of the hot water extract of Em leaves suggests their potential therapeutic value and warrants further studies.
\end{abstract}

Key words : Elaeagnus multiflora Thunb., antioxidant, cytokine, splenocyte proliferation

\section{Introduction}

Cherry elaeagnus (Elaeagnus multiflora Thunb., Em) belongs to the family Elaeagnaceae. It is cultivated as an ornamental and fruit tree, and it is naturally distributed in the wild (Saeng, 1989). The berries of Em mature in 6-7 months to a characteristic red color, with a sweet and slightly sour taste (Hong et al., 2006; Park, 2004). The leaves, stems, and roots of Em have been traditionally used for medicinal purposes. Consuming Em berries is purported to strengthen the five visceral organs. In addition, the berries are used to treat diarrhea, bleeding, dyspepsia, osteomyelitis, edema, and irregular periods (Hong et al., 2007; Yoon et al., 2007). In China, Em is also used to treat cough, itching, wounds, and even cancer (Kim, 1984). The medicinal value of the fruit of Em has been studied, and it is used in small amounts as herbal medicine. However, similar data on its leaf are limited.

The chemical constituents of Em include carbohydrates (24.1\%), crude proteins $(1.4 \%)$, crude fats $(0.4 \%)$, and crude ash (2.5\%) (Yoon et al., 2007). Meanwhile, the antiinflammatory activity of Em has been described (Lee et al., 2007), but an immune-enhanceing effect has not been reported.

\footnotetext{
*Corresponding author. E-mail : jykim761217@gmail.com, Phone :+82-61-860-2643, Fax : +82-61-864-7105
}

E-mail : blockstar@hanmail.net, Phone :+82-61-860-2620, Fax : +82-61-864-7105

Received 11 February 2020; Revised 24 March 2020; Accepted 01 April 2020.

Copyright (c) The Korean Society of Food Preservation.

This is an Open Access article distributed under the terms of the Creative Commons Attribution Non-Commercial License (http://creativecommons.org/licenses/by-nc/4.0) which permits unrestricted non-commercial use, distribution, and reproduction in any medium, provided the original work is properly cited. 
T helper (Th) cells comprise Th1 and Th2 cells. Th1 cells secrete interleukin (IL)-2 and Th2 cells secrete IL-4 and IL-10. The former are involved in delayed hypersensitivity and the latter in antibody production. Th1 and Th2 cells function exclusively in association with each other, and the cytokines they secrete are important in the immune response. IL-2, also termed T-cell growth factor (Mire-sluis and Thorpe, 1998), is secreted by $\mathrm{T}$ cells, natural killer (NK) cells, and lymphocyte-activated killer cells. IL-4, which is also termed B-cell growth factor and B-cell stimulatory factor-1, stimulates DNA synthesis in B lymphocytes. Further, IL-4 is produced mainly by $\mathrm{T}$ lymphocytes, mast cells, and basophils. The various activities of IL-4 include surface molecule expression, B-cell proliferation and differentiation, and T-cell activation. IL-10 produced by Th2 cells interferes with cytokine production in Th1 cells. Therefore, initially, this molecule was considered a cytokine synthesis inhibitory factor. However, various activities of IL-10, including inhibitory and stimulatory (Mire-sluis and Thorpe, 1998), were subsequently revealed, as was its production by other cells, including macrophages, activated $\mathrm{T}$ cells, and mast cells.

In this study, we aimed to evaluate the therapeutic use of Em leaves by evaluating the antioxidant activity and immune-enhancing effect of a hot aqueous extract of these leaves.

\section{Materials and methods}

\section{Materials and reagents}

Folin-Ciocalteu phenol reagent, 2,2-diphenyl-1-picrylhydrazyl radical (DPPH), 2,2'-azino-bis-3-ethylbenzothiazoline-6-sulfonic acid (ABTS), gallic acid, ascorbic acid, and concanavalin A (ConA) were purchased from Sigma-Aldrich (St. Louis, MO, USA). Roswell Park Memorial Institute (RPMI) 1640, Hank's balanced salt solution (HBSS), and phosphatebuffered saline (PBS) were purchased from Gibco (Carlsbad, CA, USA). Mouse IL-2, IL-4, and IL-10 ELISA kits were purchased from R\&D Systems (Minneapolis, MN, USA). Cytotox 96 non-radioactive cytotoxicity assay kit (g1780), fetal bovine serum (FBS), and Premix WST-1 Cell Proliferation Assay kit (MK400) were purchased from Promega (Madison, WI, USA), Merck (New York, NY, USA), and TaKaRa Bio, Inc. (Shiga, Japan), respectively.

\section{Preparation of extract}

Dried Em leaves (100 g) were placed in a bottle, followed by the addition of $2 \mathrm{~L}$ of distilled water. The sample was extracted at $100^{\circ} \mathrm{C}$ for $3 \mathrm{~h}$ using a reflux extractor. The extract was passed through Whatman No.41 filter paper and the filtrate was evaporated using a rotary evaporator. The evaporator bottom was freeze-dried at $-50^{\circ} \mathrm{C}$ for $48 \mathrm{~h}$ using a freeze dryer. Fifteen grams (15\%) of the extract powder obtained and was used as the experimental sample.

\section{DPPH radical scavenging activity}

DPPH radical scavenging activity was measured as previously described (McCune et al., 2002). Briefly, $10 \mu \mathrm{L}$ of sample solution and $90 \mu \mathrm{L}$ of methanol were added to wells of a 96-well plate, followed by the addition of 100 $\mu \mathrm{L}$ of $0.3 \mathrm{mM} \mathrm{DPPH}$ in ethanol. After incubating the solution in the dark for $30 \mathrm{~min}$ at $25^{\circ} \mathrm{C}$, the absorbance of the solution was measured at $517 \mathrm{~nm}$ using a microplate reader. The absorbance of blank solution containing $10 \mu \mathrm{L}$ of distilled water and $90 \mu \mathrm{L}$ of methanol was also measured. The radical scavenging activity was compared with that of vitamin C (ascorbic acid; Sigma-Aldrich) as the positive control. The activity (\%) was calculated as follows:

Free radical scavenging activity $(\%)=$

$$
\left(1-\frac{\text { Optical density }(\mathrm{O}) \text { of sample }}{\text { Optical density of control }}\right) \times 100
$$

\section{ABTS scavenging activity}

The ABTS radical scavenging activity was measured as previously described (Jeong et al., 2009). PBS (pH 7.4) was used to prepare a 1:1 dilution of $2.45 \mathrm{mM}$ ABTS potassium persulfate $(7 \mathrm{mM})$ dissolved in distilled water. The absorbance of the stock solution was $0.70 \pm 0.02$. Radial stock solution was placed in the dark for 12-16 h. Aliquots $(190 \mu \mathrm{L})$ of the stock solution were dispensed and $10 \mu \mathrm{L}$ of the sample at different concentrations was added to each. Following incubation for $7 \mathrm{~min}$ the absorbance was measured. As the positive control, vitamin $\mathrm{C}$ was used. The antioxidant activity was determined as the percentage of absorbance of the samples without and with extract. The activity (\%) was calculated as follows: 
Antioxidant activity (\%) $=$

$$
\left(1-\frac{\text { OD of control - OD of sample }}{\text { OD of control }}\right) \times 100
$$

\section{Reducing power}

The reducing power was measured using a modification of a previously described method (Oyaizu, 1986). Briefly, $200 \mu \mathrm{L}$ of each sample received $200 \mu \mathrm{L}$ each of $200 \mathrm{mM}$ PBS and $1 \%$ potassium ferricyanide. The solution was stirred at $50^{\circ} \mathrm{C}$ for $20 \mathrm{~min}$. Thereafter, $200 \mu \mathrm{L}$ of $10 \%$ trichloroacetic acid was added to the solution and the solution was centrifuged at $13,500 \times \mathrm{g}$ for $10 \mathrm{~min}$. The supernatant was collected. Then, $400 \mu \mathrm{L}$ of $0.1 \%$ ferric chloride was added to $400 \mu \mathrm{L}$ of the supernatant and the absorbance of the solution was measured at $700 \mathrm{~nm}$. The reducing power was converted to percent value of the absorbance ratio of the treatment and control groups.

\section{Total phenol content}

The total polyphenol content was analyzed using the Folin-Ciocalteu method, based on the principle that the phenolic materials reacts with phosphomolybdic acid and develops a blue color (Singleton at el., 1999). A mixture was prepared of $1 \mathrm{~mL}$ of extract $(1 \mathrm{mg} / \mathrm{mL}), 3 \mathrm{~mL}$ of distilled water, and $1 \mathrm{~mL}$ of Folin-Ciocalteu reagent. The mixture was reacted at $25^{\circ} \mathrm{C}$ for $5 \mathrm{~min}$, followed by the addition of $1 \mathrm{~mL}$ of $7 \% \mathrm{NaCO}_{3}$. The mixture was then reacted in the dark for $2 \mathrm{~h}$ and the absorbance of the solution was measured. The total polyphenol content in the sample is expressed as gallic acid equivalent per gram of sample using a standard curve of gallic acid $(6.25-100 \mu \mathrm{g} / \mathrm{mL})$.

\section{Experimental animals and breeding}

Male Balb/c mice purchased from Samtaco (Osan, Korea) were used as experimental animals to evaluate the immune-enhancing effect of the Em leaf extract. The mice were maintained under constant conditions (temperature $22 \pm 2^{\circ} \mathrm{C}$, humidity $50 \pm 5 \%$, and 12 -h light/dark cycle) for 1 week.

\section{Isolation and culture of mouse splenocytes}

Spleen cells were aseptically removed from the mice following sacrifice by cervical dislocation. The cells were washed with HBSS and rinsed with gentle rubbing against the back of the syringe piston. The cell suspension was washed twice with culture medium and centrifuged at 3,000 rpm for $10 \mathrm{~min}$. The spleen cells were dispersed in RPMI 1640 and stained with trypan blue. The cells were counted using a hemocytometer. The cell concentration was adjusted to $2 \times 10^{5}$ cells $/ \mathrm{mL}$, and $200 \mu \mathrm{L}$ of the suspension was dispensed into wells of a 96-well plate. This animal experiment was approved by the Animal Research Ethics Committee of the Natural Resources Research Center (JINR1604).

\section{Splenocyte proliferative capacity}

Six-week-old Balb/c male mice were sacrificed by cervical dislocation. The spleen was aseptically removed from each mouse and crushed through a 100-mesh to obtain single cells. The mononuclear cells were collected and centrifuged three times for $5 \mathrm{~min}$ each time at $12,000 \mathrm{rpm}$ to obtain splenocytes. The spleen cells were diluted with RPMI 1640 medium containing $10 \%$ heat-inactivated FBS to a concentration of $2 \times 10^{5}$ cells $/ \mathrm{mL}$. One hundred microliters of the suspension was dispensed into wells of a 96-well plate. ConA was added to each well and the plate was incubated at $37^{\circ} \mathrm{C}$ in a $5 \% \mathrm{CO}_{2}$ incubator for $30 \mathrm{~min}$, and then at $37^{\circ} \mathrm{C}$ for $48 \mathrm{~h}$. WST-1 (water soluble tetrazolium salts) solution was added at a concentration of $5 \mathrm{mg} / \mathrm{mL}$ and the plate was incubated in the dark for $2 \mathrm{~h}$. The absorbance of each well was measured at $440 \mathrm{~nm}$.

\section{Cytokine activity}

Splenocytes were treated with ConA $(0.1 \mu \mathrm{g} / \mathrm{mL})$ and 50 , 100 , and $200 \mu \mathrm{g} / \mathrm{mL}$ Em leaf extract, and then dispensed into wells of 96-well plates at a density of $2 \times 10^{5}$ cells $/ \mathrm{mL}$. After 24 and $48 \mathrm{~h}$, the culture supernatant was collected. After incubation at $4^{\circ} \mathrm{C}$ for $30 \mathrm{~min}$ at $1{ }^{\circ} \mathrm{C}$ or lower, the cells were flushed with wash solution for $2 \mathrm{~h}$ and $200 \mu \mathrm{L}$ of reagent diluent was dispensed into each well. After $1 \mathrm{~h}$, each sample was washed twice and $100 \mu \mathrm{L}$ of the culture supernatant was incubated for $2 \mathrm{~h}$ at room temperature. The supernatant was washed twice and dispensed $(100 \mu \mathrm{L})$ into a working detector and incubated at room temperature for $2 \mathrm{~h}$. After two washes, $100 \mu \mathrm{L}$ of horseradish peroxidase -conjugated streptavidin was added and incubated for $20 \mathrm{sec}$ at room temperature. After washing twice, $100 \mu \mathrm{L}$ of the supernatant was incubated for a maximum of $40 \mathrm{~min}$. 
Finally, $50 \mu \mathrm{L}$ of the solution was used to measure the absorbance at $450 \mathrm{~nm}$.

\section{NK cell activity}

YAC-1 cells were purchased form the Korea cell line bank. Yac-1 cells and mouse spleen cells were cultured in RPMI 1640 medium containing 10\% FBS and 1\% penicillin at $37^{\circ} \mathrm{C}$. After incubation in a $5 \% \mathrm{CO}_{2}$ incubator, $50 \mu \mathrm{L}$ of $B A L B / c$ mouse splenocytes $\left(1 \times 10^{6}\right.$ and $5 \times 10^{5}$ cells $\left./ \mathrm{mL}\right)$ and $50 \mu \mathrm{L}$ of YAC- 1 cells $\left(2 \times 10^{5}\right.$ cells $\left./ \mathrm{mL}\right)$ were seeded in wells of a 96-well plate. Subsequently, 50, 100, or $200 \mu \mathrm{g} / \mathrm{mL}$ of Em leaf extract was added and the plate was incubated at $37^{\circ} \mathrm{C}$ in a $5 \% \mathrm{CO}_{2}$ incubator for $4 \mathrm{~h}$. After adding $10 \mu \mathrm{L}$ of $10 \times$ lysis buffer $45 \mathrm{~min}$ before the end of the reaction, the cells were re-cultured and centrifuged at 2,500 rpm for $4 \mathrm{~min}$. Subsequently, $50 \mu \mathrm{L}$ of the supernatant was transferred into wells of a 96-well plate, $50 \mu \mathrm{L}$ of substrate mix was added, and the mixture was incubated in the dark for $30 \mathrm{~min}$ at room temperature. After stopping the reaction by adding $50 \mu \mathrm{L}$ of stop solution to each well, the absorbance of the sample was measured at $490 \mathrm{~nm}$ using a microplate reader.

\section{Statistical analysis}

We compared the resulting metabolic activities of the treatment groups and controls using one-way analysis of variance and Dunnett's multiple-comparison posttest. Differences between groups were considered significant at a p-value $<0.05$. Statistical analyses were performed using GraphPad Prism 5.0 (GraphPad Software, Inc., La Jolla, CA, USA).

\section{Results and discussion}

\section{Radical scavenging activity}

The ABTS and DPPH assays are widely used to measure antioxidant activities using relatively stable free radicals. ABTS produces cation radicals and DPPH produces anion radicals. Therefore, the two methods differ in the degree of binding between the substrate and reactant. and the results differ between the methods. The DPPH radical scavenging activity of the Em leaf extract was $16.6 \%, 32.5 \%$, and $58.5 \%$ at 50,100 , and $200 \mu \mathrm{g} / \mathrm{mL}$, respectively. The DPPH radical scavenging activity of $100 \mu \mathrm{g} / \mathrm{mL}$ vitamin $\mathrm{C}$ was 93.4\%. The DPPH radical scavenging activity increased significantly as the concentration of the hot water extract of Em leaves increased. In the ABTS method, the antioxidant activity is measured by exploiting the fact that ABTS produced by reaction with potassium persulfate is removed by the antioxidants in the sample, resulting in discoloration. The ABTS radical scavenging activity with 50, 100, and 200 $\mu \mathrm{g} / \mathrm{mL}$ of extract was $22.0 \%, 41.4 \%$, and $73.2 \%$, respectively, and that of $100 \mu \mathrm{g} / \mathrm{mL}$ vitamin $\mathrm{C}$ was $94.6 \%$. The DPPH radical scavenging activity of hexane, dichloromethane, and acetyl acetate fruit extracts of Em has been reported to be $62.92 \pm 2.45,65.25 \pm 4.74$ and $98.83 \pm 0.02 \%$, respectively (Kim, 2007). The results of the present study confirmed that, similar to the fruits, the leaves of Em also exhibit DPPH radical scavenging activity (Fig. 1).

\section{Reducing power and total phenol content}

Reducing power is determined by measuring the intensity of blue Perl's Prussian blue at $700 \mathrm{~nm}$, which is due to the reduction of the $\mathrm{Fe}^{3+} /$ ferricyanide complex (potassium ferricyanide (III)) by antioxidants into the ferrous form. The absorbance value indicates the reducing power of the sample. Higher the absorbance value, indicate increase reducing power. The absorbance value the of hot water extract of Em leaves at concentrations of 50,100 , and $200 \mu \mathrm{g} / \mathrm{mL}$ was $0.118 \pm 0.002,0.185 \pm 0.006$, and $0.312 \pm 0.002$, respectively, which were higher than that of the control group (100 $\mu \mathrm{g} / \mathrm{mL}$ ascorbic acid, 2.196 \pm 0.027 ).

Phenolic compounds exhibit a high antioxidant activity as secondary metabolites and are widely distributed in nature. The hydroxyl group of an aromatic compound binds to phenolic compounds. Thus, when exposed to active oxygen, phenolic compounds exhibit antioxidant and anti-cancer activities. They also protect DNA, cellular constituents, and enzymes from damage. The total phenolic content of the hot water extract of Em leaves was $31.687 \pm 4.904 \mathrm{TAE} / \mathrm{g}$, and the leaves of Em are considered to have higher antioxidant activity than the fruits (Fig. 2). The polyphenol content in the leaves has been reported to be $805.6 \mathrm{mg} / 100 \mathrm{~g}$ (Yoon et al., 2007).

\section{Proliferation of spleen cells}

To investigate the effect of Em leaf extracts on ConAinduced responses in splenocytes, splenocytes were isolated from mice and cultured by adding only the Em leaf extract 
(A)

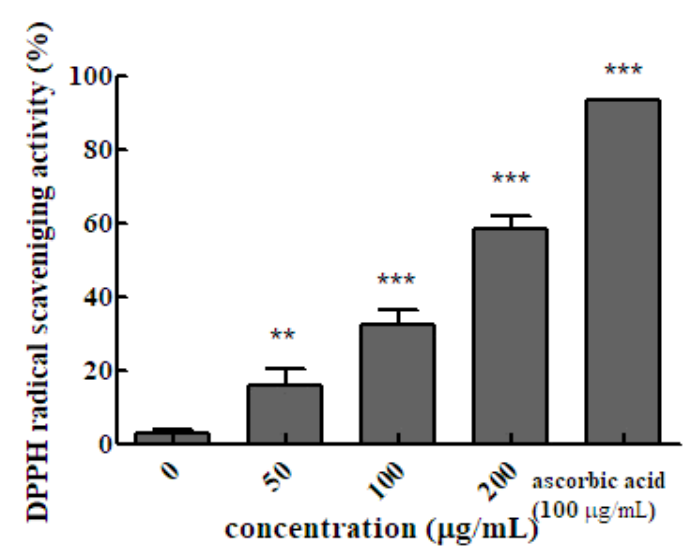

(B)

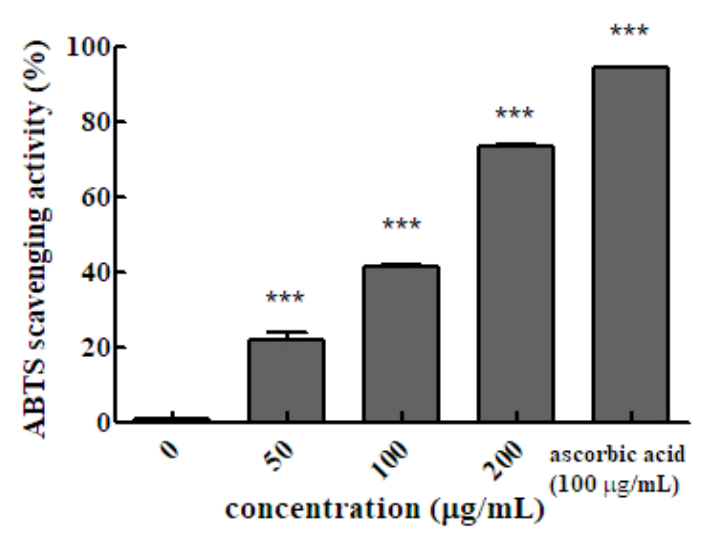

Fig. 1. Radical Scavenging activities of Elaeagnus multiflora Thunb. leaf extract at various concentrations assessed by percentage inhibition of DPPH (A) and ABTS (B) radicals.

Results are the mean $\pm \mathrm{SD}$ of three independent experiments and all experiments were performed in triplicate.

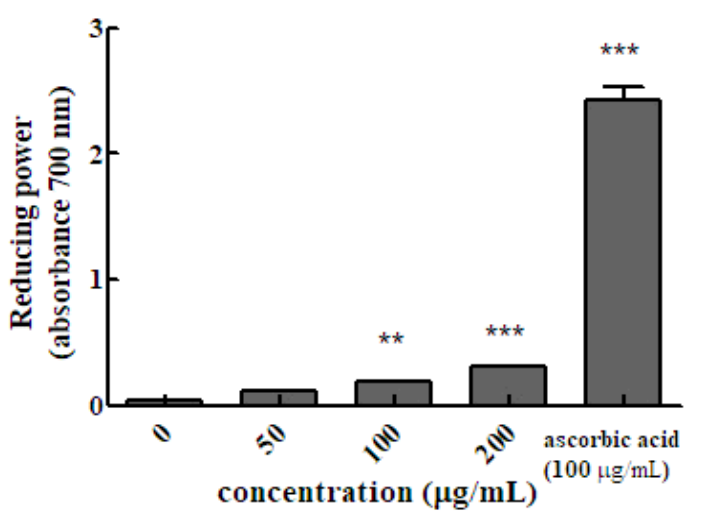

Fig. 2. Reducing power of Elaeagnus multiflora Thunb. leaf extract at various concentrations.

Results are the mean $\pm \mathrm{SD}$ of three independent experiments and all experiments were performed in triplicate. to the culture medium. As shown in Fig. 3, the absorbance value of the group cultured with the ConA mitogen was higher than that of the group cultured without the mitogen. It was also confirmed that splenocyte proliferation was increased. The absorbance of the cell suspension with the Em leaf extract at different concentrations (50, 100, and 200 $\mu \mathrm{g} / \mathrm{mL})$, measured after $48 \mathrm{~h}$ of treatment increased $(0.241 \pm$ $0.011,0.242 \pm 0.031$, and $0.328 \pm 0.004$, respectively) compared to the value of $0.233 \pm 0.030$ in the extract-free splenocyte control. The increase in absorbance in the $200 \mu \mathrm{g} / \mathrm{mL}$ treatment group was 1.5 -fold higher than that in the control group.

\section{Cytokine measurement}

We next evaluated the effect of the hot water leaf extract of Em on the ability of spleen cells to produce the IL-2, IL-4, and IL-10 cytokines following induction by ConA. Spleen cells of Balb/c mice were treated with different concentrations of the extract and cultured for $48 \mathrm{~h}$. The levels of IL-2, IL-4, and IL-10 in the culture were measured.

In the immune response, IL-2 is important for signal transduction between cells in the initial inflammatory responses (Barnes and Liew, 1995). IL-2 is widely used as an indicator of enhanced immune response (Grabstein et al., 1994). To confirm the immune-enhancing effect, we

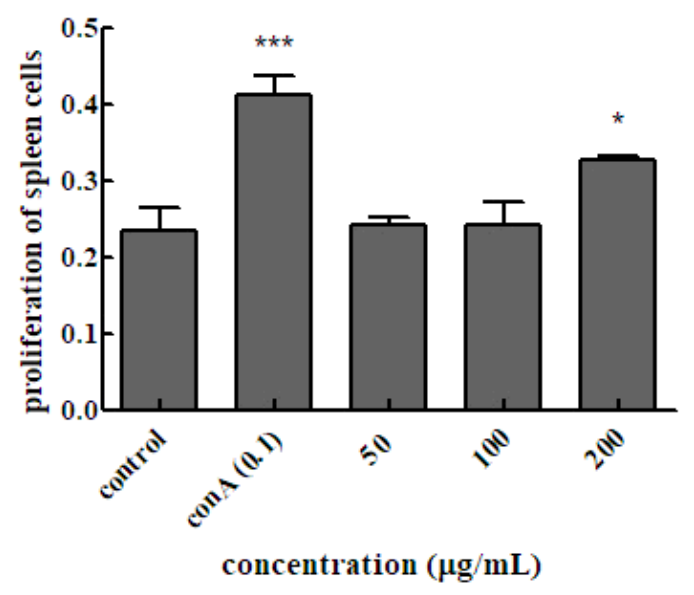

Fig. 3. Effects of Elaeagnus multiflora on the proliferation of mouse splenocytes in vitro.

Mouse splenocytes were stimulated with ConA mitogen in the presence of various concentrations of $E$. multiflora extract for $48 \mathrm{~h}$. Splenocyte proliferation was assessed using the WST-1 assay. The results are the mean $\pm \mathrm{SD}$ of three independent experiments and all experiments were performed in triplicate. 
measured the level of IL-2, a Th1 cytokine secreted by mouse spleen Th cells. IL-2 is secreted by activated T cells and is primarily a cytokine that primarily acts as a T-cell growth factor by promoting T-cell division. Increased level of $\mathrm{T}$ lymphocytes can be used as an index of the effect of IL-2. Spleen cells treated with ConA, which activates only $\mathrm{T}$ cells, and those treated with only the extract were cultured for $48 \mathrm{~h}$, and then IL-2 levels were measured. The IL-2 level was $2.298 \pm 0.321$ in the control group and $1.451 \pm$ $0.149,1.583 \pm 0.133$, and $1.855 \pm 0.171 \mathrm{pg} / \mathrm{ml}$ in the 50,100 , and $200 \mu \mathrm{g} / \mathrm{mL}$ treatment groups, respectively (Fig. 4A).

Th2 cells play a major role in humoral immunity by producing antibodies and suppressing the action of Th1 cells. In the immune system, Th2 cells maintain homeostasis due to the Th1/Th2 cell balance (Seo et al., 2013). We measured IL-4 and IL-10 in Th2 cells. IL-4 is secreted by $\mathrm{T}, \mathrm{B}$, and NK cells, monocytes, macrophages, neutrophils, eosinophils, vascular endothelial cells, and fibroblasts. It targets and induces the differentiation and proliferation of Th2 cells and simultaneously increases the number of CD4 $+\mathrm{T}$ cells (Seo et al., 2013). Spleen cells treated with ConA and those treated with only the extract were cultured for 48 $\mathrm{h}$, and then IL-4 levels were measured. The IL-4 level was $41.574 \pm 6.678$ in the control group and 24.556 \pm 9.219 , $23.407 \pm 0.262$, and $37.630 \pm 0.576 \mathrm{pg} / \mathrm{mL}$ in the 50,100 , and $200 \mu \mathrm{g} / \mathrm{mL}$ treatment groups, respectively (Fig. 4B).

IL-10 targets monocytes, macrophages, T cells, B cells, NK cells, and mast cells. It is an anti-inflammatory cytokine that acts directly on $\mathrm{T}$ cells and macrophages to suppress cell activation (Yi et al., 2013) and is an inhibitory cytokine that suppresses the immune system (Sohn et al., 2012). Spleen cells treated with ConA and those treated with only the extract were cultured for $48 \mathrm{~h}$, and then IL-10 levels were measured. The IL-10 level in the control cells was $239.111 \pm 43.299 \mu \mathrm{g} / \mathrm{mL}$, whereas that in the treatment groups $(50,100$, and $200 \mu \mathrm{g} / \mathrm{mL})$ was $252.250 \pm 96.284$, $196.500 \pm 84.297$, and $236.167 \pm 22.156 \mu \mathrm{g} / \mathrm{mL}$, respectively (Fig. 4C).

\section{NK cell cytotoxicity}

NK cells secrete water soluble factors, including cytokines, that can directly kill cancer cells and cells infected by intracellular microorganisms. NK cells can also activate other predatory cells, such as monocytes and
(A)

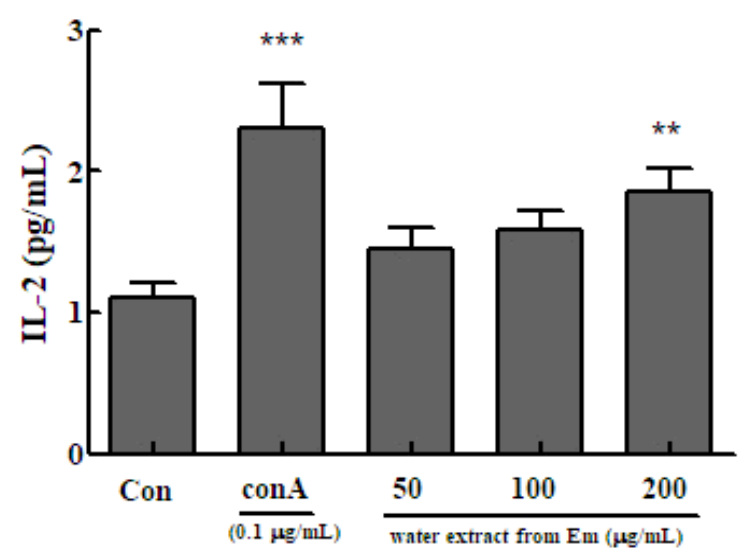

(B)

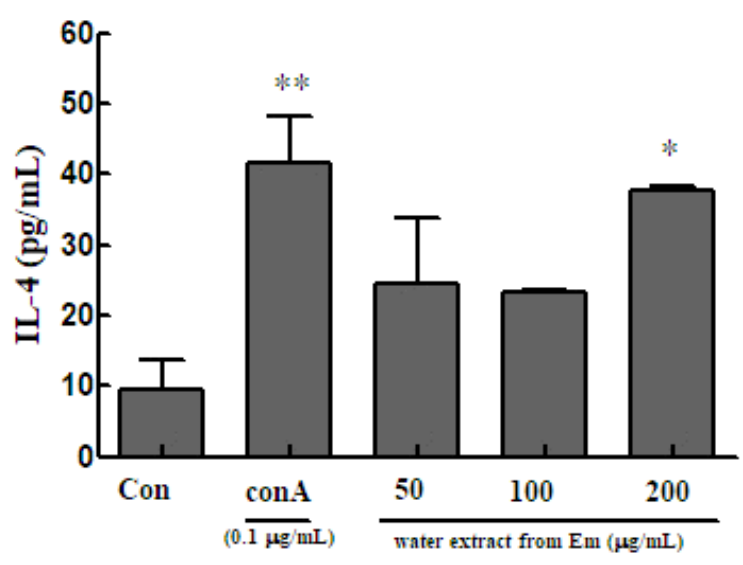

(C)

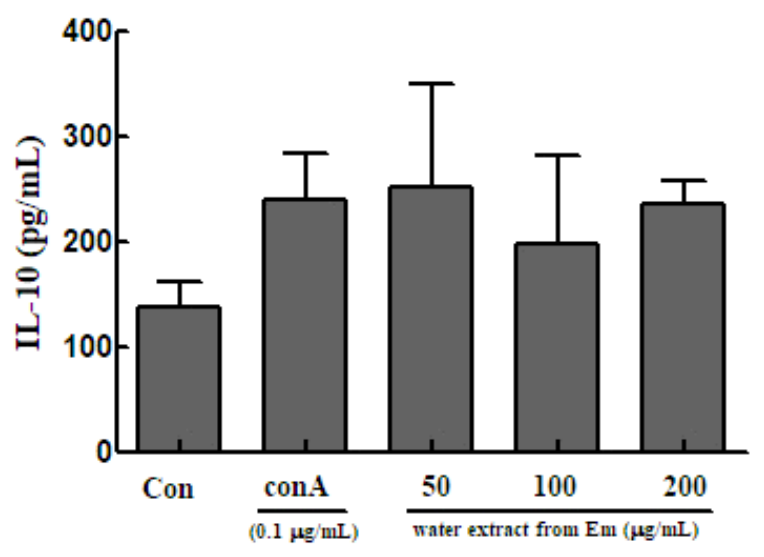

Fig. 4. Interleukin secretion by spleen cells that were untreated or treated with the concanavalin A (ConA) or the indicated concentrations of Elaeagnus multiflora extract.

Spleen cells were cultured as described in Fig. 3. After 1 day of treatment, the supernatants were collected and quantified for IL-2 (A), IL-4, (B), and IL-10 (C). Data are the mean \pm SD of four individual wells. 


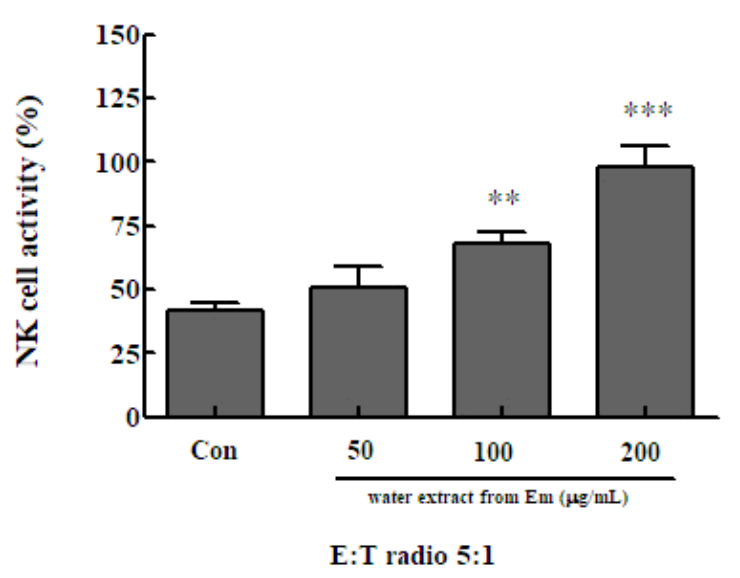

Fig. 5. Cytotoxicity of natural killer (NK) cells isolated from $B a l b / c$ mouse spleen lymphocytes against YAC-1 cells.

The cytotoxicity levels in YAC-1 cells after co-culture for $4 \mathrm{~h}$ are presented. The ratio of the mixture of lymphocytes and YAC-1 cells is presented on the $\mathrm{x}$-axis. The relative cytotoxicity levels are expressed as the mean $\pm \mathrm{SE}(\mathrm{n}=3)$.

dendritic cells. Immune cells play a major role in innate immunity (Song et al., 2008). To determine the NK cell activity following treatment with the Em leaf extract, NK cells were isolated from spleen cells and co-cultured with Yac-1 mouse lymphoma cells. Cell-killing ability was evaluated using the Cytotox 96 non-radioactive cytotoxicity assay kit. NK cell activity was significantly increased in the presence of $100 \mu \mathrm{g} / \mathrm{mL}(67.874 \pm 4.877 \%)$ and $200 \mu \mathrm{g} / \mathrm{mL}$ (97.975 $\pm 8.598 \%$ ) of the Em extract, compared with activity in the extract-free control group (41.985 $\pm 2.604 \%$ )(Fig. 5). The activity of NK cells of the treatment group was significantly higher than that of the control group at all extract concentrations.

\section{Acknowledgment}

This work was supported by the Support Program for Creative Industry Institutes (Commercial Bio-technology Sophistication Platform Construction Program, R0003950); and the Technology Innovation Program (10051145) funded by the Ministry of Trade, Industry \& Energy (MOTIE, Korea).

\section{Conflict of interests}

The authors declare no potential conflict of interest.

\section{ORCID}

\author{
Mi Ri Kim \\ https://orcid.org/0000-0002-5502-8081 \\ Jaeyong Kim \\ http://orcid.org/0000-0003-4810-7635 \\ Chul Yung Choi \\ https://orcid.org/0000-0003-2006-635X
}

\section{References}

Barnes PJ, Liew FY. Nitric oxide and asthmatic inflammation. Immunol Today, 16, 128-130 (1995)

Grabstein KH, Eisenman J, Shanebeck K, Rauch C, Srinivasan S, Fung V, Beers C, Richardson J, Schoenborn MA, Ahdieh M, Johnson L, Alderson MR, Watson JD, Anderson DM, Giri JG. Cloning of a T cell growth factor that interacts with the $\beta$ chain of the interleukin-2 receptor. Science, 264, 965-968 (1994)

Hong JY, Nam HS, Lee YS, Yoon KY, Kim NW, Shin SR. Anti-oxidant activity of ethanol extracts from fruits of Elaeagnus multiflora THUNB. during maturation. Korean J Food Preserv, 13, 643-648 (2006)

Hong JY, Cha HS, Shin SR, Jeong YJ, Youn KS, Kim MH, Kim NW. Optimization of manufacturing condition and physicochemical properties for mixing beverage added extract of Elaeagnus multiflora Thunb. fruits. Korean J Food Preserv, 14, 269-275 (2007)

Jeong YS, Jung HK, Youn KS, Kim MO, Hong JH. Physiological activities of the hot water extract from Eriobotrya japonica Lindl.. J Korean Soc Food Sci Nutr, 38, 977-982 (2009)

Kim JG. Illustrated Natural Drugs Encyclopedia, vol 1. Namsadang, Seoul, Korea, p 279 (1984)

Kim SA, Oh SI, Lee MS. Antioxidative and cytotoxic effects of solvent fractions from Elaeagnus multiflora. Korean J Food Nutr, 20, 134-142 (2007)

Lee YS, Chang ZQ, Oh BC, Park SC, Shin SR, Kim NW, Antioxidant activity, anti-inflammatory activity, and whitening effects of extracts of Elaeagnus multiflora Thunb.. J Med Food, 10, 126-133 (2007)

Mire-Sluis AR, Thorpe R. Cytokines. Academic Press, Cambridge, MA, USA, p 19-400 (1998)

McCune LM, Johns T. Antioxidant activity in medicinal plants associated with the symptoms of diabetes mellitus used by the indigenous peoples of the North American boreal forest. J Ethnopharmacol, 82, 197-205 (2002)

Oyaizu M. Antioxidative activities of browning reaction 
prepared from glucosamine. Jpn J Nutr, 44, 307-315 (1986)

Park JH. Medicinal Plants of Korea, Shinil Sangsa, Seoul, Korea, p 953-954 (2004)

Saeng CM. Illustrated Primary Color Trees in Korea. Academy Press, Seoul, Korea, p 372 (1989)

Singleton VL, Orthofer R, Lamuela-Raventos RM. Analysis of total phenols and other oxidation substrates and antioxidants by means of Folin-Ciocalteu reagent. Methods Enzymol, 299, 152-178 (1999)

Song JJ, Cho JG, Hwang SJ, Cho CG, Park SW, Chae SW. Inhibitory effect of caffeic acid phenethyl ester (CAPE) on LPS-induced inflammation of human middle ear phithelial cells. Acta Oto-Laryngol, 128, 1303-1307 (2008)

Sohn EH, Yoon JW, Koo HJ, Park DW, Jeong YJ, Namkoong S, Han HS, Kang SC. Immunomodulating effects of red ginseng on the regulation of cytokine release in vivo.
Korean J Plant, 25, 578-585 (2012)

Seo MJ, Kang BW, Park JU, Kim MJ, Lee HH, Ryu EJ, Joo WH, Kim KH, Jeong YK. Effect of black garlic extract on cytokine generation of mouse spleen cells. J Life Sci, 23, 63-68 (2013)

Yi JW, Jang MH, Choi JS, Ahn TW. The effect of Yongyukjowitang distillate on the immune activity of spleen cells of aged rats. J Sasang Constitut, 25, 218232 (2013)

Yoon KY, Hong JY, Nam HS, Moon YS, Shin SR. Antioxidant activities and xanthine oxidase inhibitory effects of hot-water extracts from fruits of Elaeagnus multiflora Thunb. in maturity. J Korean Soc Food Sci Nutr, 36, 14-19 (2007)

Yoon KY, Hong JY, Shin SR. Analysis on the components of the Elaeagnus multiflora Thunb. leaves. Korean J Food Preserv, 14, 639-644 (2007) 